\title{
Detection of transovarial transmission of dengue virus in Aedes spp. (Diptera: Culicidae) from Brontokusuman Village, Yogyakarta, Indonesia
}

\author{
DILA HENING WINDYARAINI", TITI MARSIFAH, YAHYA MUSTANGIN, \\ SOENARWAN HERY POERWANTO ${ }^{\text {}}$ \\ Faculty of Biology, Universitas Gadjah Mada. Jl. Teknika Selatan, Sleman 55281, Yogyakarta, Indonesia. Tel./fax.: +62-274-580839, \\ "email: dila.windyaraini@ugm.ac.id, ^v soenarwan@ugm.ac.id
}

Manuscript received: 3 April 2019. Revision accepted: 30 June 2019.

\begin{abstract}
Windyaraini DH, Marsifah T, Mustangin Y, Poerwanto SH. 2019. Detection of transovarial transmission of dengue virus in Aedes spp. (Diptera: Culicidae) from Brontokusuman Village, Yogyakarta, Indonesia. Biodiversitas 20: 2061-2067. Dengue Hemorrhagic Fever (DHF) is an infectious vector-borne disease. It is caused by dengue virus infection through the vector of Aedes spp. Dengue virus can be transmitted transovarially from infected female mosquitoes to their eggs. The presence of transovarial transmission allows maintenance of serotypes of dengue virus in nature. Detection of transovarial transmissions can be used to predict disease outbreaks as an effort to control the dengue virus. Dengue control is generally carried out through control of dengue vectors (mosquitoes) with environmental management, the use of chemical agents (insecticides) and biological control. This study was conducted to determine the existence of transovarial (vertical) transmission, factors affecting it and the resistance status of Aedes spp. against cypermethrin insecticide (pyrethroid) in Brontokusuman Village, Mergangsan Sub-district of Yogyakarta, Indonesia. The study was conducted from September 2018 to February 2019 with larvae sampling in 100 houses. The adult Aedes spp. mosquitoes were used as the sample of immunohistochemical methods and bioassay to get the mosquito resistance status against cypermethrin. The transovarial transmission of dengue virus in Aedes spp. from Brontokusuman Village was found in 3 of 100 samples of Aedes spp. mosquitoes, and the TTI value (Transovarial Transmission Index) was 3\%. The transovarial transmission is influenced by the density of the infected vectors, the condition of their eggs and the number of dengue cases. The bioassay test results showed that the resistance status of Aedes spp. can be presumed resistance against cypermethrin insecticide.
\end{abstract}

Keywords: Dengue virus, DHF, immunohistochemistry, resistance, transovarial

Abbreviations: Ae: Aedes; sp./spp.: species; DHF: Dengue Hemorrhagic Fever; RW: Rukun Warga, TTI: Transovarial Transmission Index

\section{INTRODUCTION}

Dengue Hemorrhagic Fever (DHF) is one of diseases of main focus in the health sector in Indonesia. At the beginning of dengue cases in Indonesia, there were only 58 cases. This number increased to 68,407 cases in 2017 . Higher mobility and population density might be the possible causes behind the increase in DHF cases. The DHF cases also occurred in the Special Region of Yogyakarta with 1,642 cases, of which 394 cases occurring in the Yogyakarta city (Kemenkes 2018).

The DHF is caused by the dengue virus, with Aedes aegypti as the major mosquito vector. Another mosquito species, Aedes albopictus is suggested for being a secondary DHF vector. The spread of the virus can also occur through the intermediary of the A. albopictus mosquito. Both of these mosquito species can be found in the tropical area, by breeding larval phases in waterlogged places especially in containers (Ramadhani et al. 2017; Reiskind and Zarrabi 2012).

The dengue virus is one of the genera of Flavivirus. The virus has four serotypes including DENV-1, DENV-2, DENV-3, and DENV-4 that has been classified according to their serological characteristics (Lee et al. 2013). The dengue virus is transmitted through the intermediary of Aedes spp. female while sucking the infected human blood (Kemenkes 2005).

The transmission of dengue virus occurs through the process of horizontal and vertical transmission (transovarial). The horizontal virus transmission occurs when dengue viruses came from infected humans are transmitted to other healthy humans with vector intermediaries (Mardihusodo et al. 2007). On the other hand, transovarial transmission occurs when the dengue virus is transmitted by female mosquitoes to their offspring via eggs (Angel and Joshi, 2008). The mechanism of transovarial transmission allows survival and maintenance of viruses in nature. The ability of eggs to survive in good or bad environmental conditions for long periods of time helps the virus survival and maintenance inside mosquito eggs (Mulyatno et al. 2012). The existence of transovarial transmission has the potential to cause an increase in dengue outbreaks in endemic areas (Thavara et al. 2006). Transovarial virus transmission has occurred in several areas in Indonesia. Pramestuti et al. (2013) reported that transovarial dengue virus infection in the Banjarnegara 
Regency area has been reached up to $11.79 \%$. Transovarial transmission has also been found in the special region of Yogyakarta. A study conducted by Satoto et al. (2018) at Adisucipto Airport revealed that, the lowest percentage of the incidence of transovarial transmission has been reached to $16.1 \%$. Transovarial transmission was also reported in the city of Yogyakarta with a percentage of $16.16 \%$ (Umniyati 2009). The existence of transovarial transmission is influenced by several factors, including the ability of the vector to transmit viruses, density and vector behavior (Yacoub and Farrar 2014). The factors influencing existence of transovarial transmission are of two types namely climatic factors (temperature and humidity) and non-climatic factors (social factors) (Halstead 2008; Thongrungkiat et al. 2010). Apart from these, dengue virus transmission is also caused by risk factors which include climate, rainfall, mobility, and population density (Depkes 2005). Moreover, the morbidity and mortality of dengue virus infection can be influenced by host immune status, the dengue virus transmission, the virulence of dengue virus and local geographic condition (Depkes 2005).

Detection of dengue virus transmitted in trans-ovaries can be developed as an effort to control their transmission. The earliest detection of the presence of dengue virus derived from mosquito eggs can be used to forecast the possibility of disease outbreaks (Rohani et al. 2007). Immunohistochemical methods on mosquito head squash or abdominal squash preparations can be used in virus detection process (Umniyati et al. 2008).

The control of the spread of viruses is generally focused on controlling the mosquito vectors. Some efforts which were made to control the spread of viruses include environmental management, use of insecticides and biological control agents. However, the continuous use of insecticides for longer duration has developed resistance among mosquito (vector) to insecticides (WHO 2009).

This study was aimed to determine the existence of transovarial transmission of dengue virus, factors affecting and the resistance status of Aedes spp. (Diptera: Culicidae) against cypermethrin in the Brontokusuman Village of Mergangsan Sub-district, Indonesia, which is an endemic area of DHF in the Yogyakarta city.

\section{MATERIALS AND METHODS}

\section{Study area}

The study was conducted in Brontokusuman Village of Mergangsan Sub-district, Yogyakarta City, Indonesia (Figure 1). The sampling was done in 100 houses which were selected randomly. Amount 100 houses can be divided to five sampling sites with 20 houses in each location and named as RW (Rukun Warga) RW 4, RW 7, RW 9, RW 13, and RW 18.

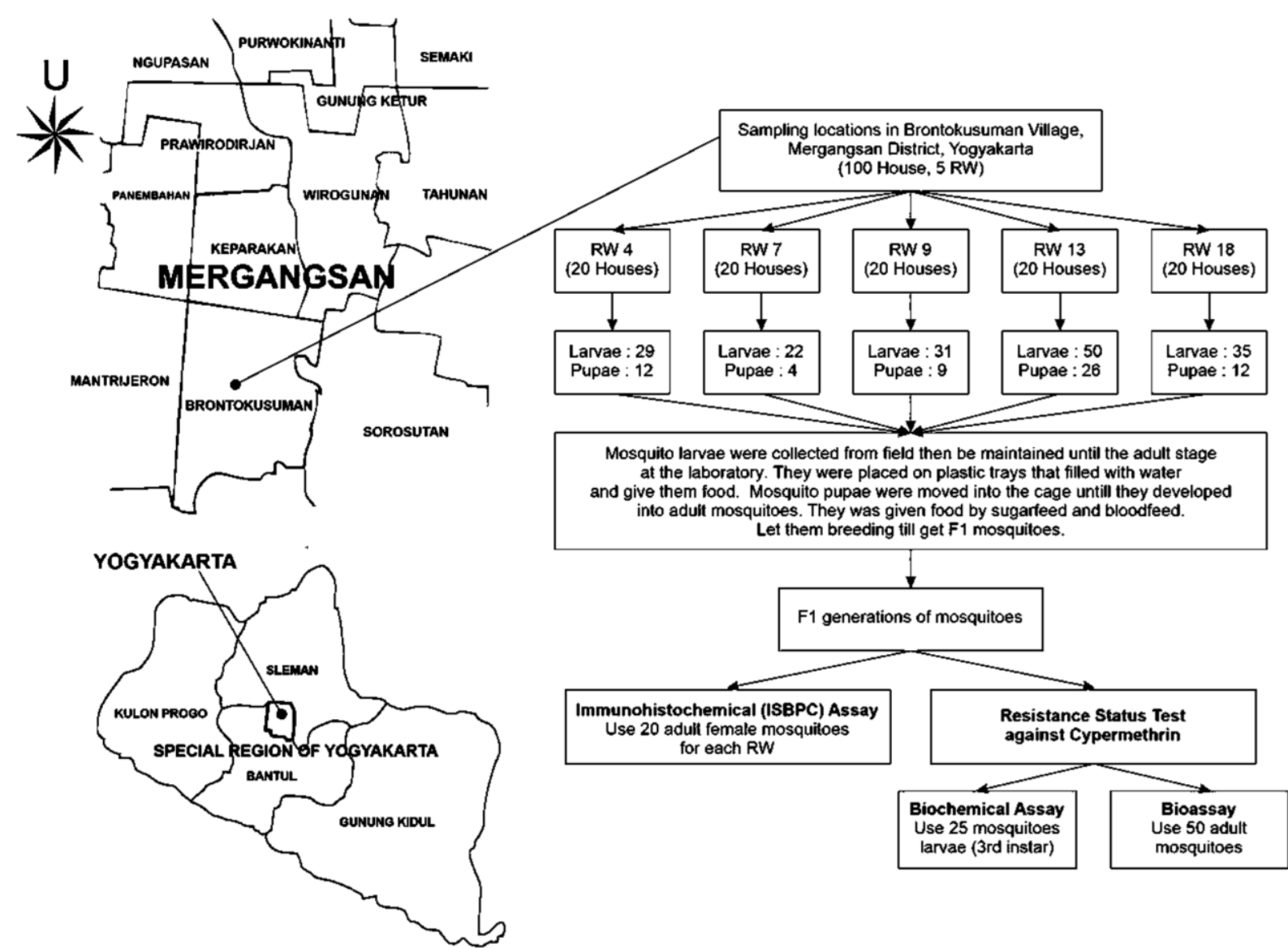

Figure 1. Research design for detection transmission trans-ovary and resistance status assay in Brontokusuman Village, Mergangsan Sub-district, Yogyakarta City, Indonesia (Note: RW= Rukun Warga) 


\section{Procedures}

Mosquito larvae were collected from sampling locations and transported to Animal Systematic Laboratory of the Faculty of Biology, Universitas Gadjah Mada. These larvae were subjected to rearing procedures and then maintained until the adult stage. In laboratory, mosquito larvae were placed on water-filled plastic trays and then moved into the cages where they developed into adult mosquitoes. Let them breeding till F1 mosquitoes obtained. Only female mosquitoes from F1 generations were used as samples for immunohistochemical assay. The immunohistochemical assay and resistance status of the larvae collected in these place were carried out in the Parasitology Laboratory of the Faculty of Medicine, Universitas Gadjah Mada.

\section{Immunohistochemical assay (ISBPC: \\ Immunohistochemistry Streptavidin Biotin Peroxidase Complex) using the head squash method}

Immunohistochemical assay method refers to the standard procedure of the Parasitology Laboratory, Faculty of Medicine UGM (Umniyati 2009). The female mosquitoes of F1 generation (adult stage) from Brontokusuman, along with positive and negative control were knocked down at first. The average age of female mosquitoes used was 7 days. It aims to give time for the dengue virus to replicate. The thorax and head of the mosquito were separated by using dissecting tweezers. The mosquito head was placed on the poly L- Lycin slide and covered with a cover glass, and then squashed (pressed slowly and carefully). The head squash preparations were fixed with cold absolute methanol and incubated for 5 minutes or until dry at room temperature. The preparation slides were washed with peroxidase blocking solution (PBS) with $\mathrm{pH} 7.4$ for 5 minutes and then submerged and incubated for another 10 minutes. The slides were washed with running water and dried. The preparations slides were then washed again with PBS pH 7.4) for 5 minutes. After that $30 \mu \mathrm{L}$ of blocking serum was added to each slide, mixed well and stored for 10 minutes on wet tissue paper. Monoclonal primary antibody was diluted with PBS (1: 10). About $100 \mathrm{ml}$ of the diluted solutions were added to each slide and left for 1 hour on wet tissue paper. The preparations slides were washed with PBS ( $\mathrm{pH}$ 7.4) for 2 minutes, 3 times. Then $50 \mathrm{~mL}$ of biotin was added to each slide and left for 20 minutes on wet tissue paper. The preparations slides were washed 3 times with PBS (pH 7.4) for 2 minutes. The $50 \mu \mathrm{l}$ of streptavidin was added on each slide and left for 10 minutes on wet tissue paper. The slides again were washed with PBS (pH 7.4) for 2 minutes 3 times. Then $100 \mu \mathrm{l}$ (Diaminobenzidine or DAB) was added to each slide and left for 5-10 minutes and were washed with running water and dried. The slides were treated with HE (Hematoxylin-Eosin) dye for 2 minutes and washed with running water and dried. The slides were dipped in absolute alcohol (95\%), added with Canada Balsam, covered with cover glass and then dried. The ISBPC (Immunohistochemistry Streptavidin Biotin Peroxidase Complex) method was used to maintain positive and negative controls. The positive control was adult female $A$. aegypti mosquitoes that had been infected by Den-3 virus by interthoracic way. Before injected, the virus was inoculated in a gelatinous medium at least 5 days old. The DENV-3 serotypes include serotype of the dominant dengue virus found in Indonesia (Andriyoko et al. 2012). The negative control was adult female Culex sp. mosquitoes which are not a vector of dengue virus, so they do not contain dengue virus in their bodies. Both types of these mosquitoes were obtained from the Laboratory of Parasitology of the Faculty of Medicine, UGM.

\section{Detection of cypermethrin resistance mechanism using biochemical assay}

The mechanism of cypermethrin resistance through observation of enzyme monooxygenase activity, carried out by reference to the WHO method (2000). The F1 mosquito larvae generation from Brontokusuman were crushed with $50 \mu \mathrm{l}$ PBS and then diluted with $150 \mu \mathrm{l}$ PBS. About $20 \mu \mathrm{l}$ homogenate followed by $80 \mu \mathrm{l}$ of phosphate potassium buffer was added into the well on the microplate. $200 \mu \mathrm{l}$ mixture solution of TMBZ (Tetramethylbenzidine) and Sodium Acetate Buffer were added into the well. And then the $3 \%$ hydrogen peroxide was added to the well as much as $25 \mu \mathrm{l}$ and left for 2 hours. The color intensity of the solution in the well was observed at $655 \mathrm{~nm}$ wavelength by an immunoassay reader.

\section{Biological assay of resistance status against cypermethrin insecticide}

Resistance status assay was carried out by bioassay referring to the CDC (Centers for Disease Control and Prevention) Bottle Assay Method (Brogdon and Chan 2010). The cypermethrin $(25 \mu \mathrm{g} / \mathrm{l})$ was dissolved in acetone, with a concentration of cypermethrin in the mixture of $10 \mu \mathrm{g}$ (CDC standard). The five test bottles were prepared of which 4 bottles of treatment were filled with $1 \mathrm{ml}$ mixture of cypermethrin and acetone solution, whereas the 5th bottle was filled with $1 \mathrm{ml}$ acetone and served as control. The bottle was rotated and rolled so that the solution well covered to the wall of bottles. The bottles were labeled and kept for 24 hours. The ten female Aedes spp. mosquitoes were put in each bottle. This number of mosquito can be raised with reference to procedure given by Kemenkes (2018) which states that for the bioassay test 10-25 mosquitoes can be used. The bottles were covered with gauze. The number of knocked-down mosquitoes was checked every 15 minutes until 2 hours. Then the mosquitoes were moved into labeled paper cups and feed with sugar water.

\section{Data analysis}

Analysis of data so obtained from observations was determined qualitatively based on the color of the preparation. The percentage of transovarial transmission was calculated quantitatively by the Transovarial Transmission Index/TTI, with the following formula (Purnama et al. 2017).

TTI $=$ (number of mosquitoes positive for dengue virus/number of mosquitoes examined) x $100 \%$ 
The mechanism of cypermethrin resistance status using biochemical assay was analyzed from the results of the Absorbance Value (AV) with $\lambda=655 \mathrm{~nm}$. The grouping criteria were divided into three categories, namely AV value < negative control mean +3 SD means very sensitive; negative control level $+3 \mathrm{SD} \leq \mathrm{AV}$ positive control rate categorized moderate resistant; $\mathrm{AV}>$ positive control rate means high resistant. The cut-off positive value was obtained from the mean $\mathrm{AV}$ value of negative control +3 SD (Biswas et al. 2011).

The resistance status of Aedes spp. against cypermethrin insecticide was determined by category based on the percentage of the mosquito mortality. The resistance status category was $\geq 98 \%$ means susceptibility, $80-97 \%$ means presumed resistance and $<80 \%$ means can be stated resistant (Kemenkes 2018).

\section{RESULTS AND DISCUSSION}

\section{Detection of transovarial transmission dengue virus}

From the result of ISBPC method, the head squash sample will be stained and change into brown color for positive sample and negative sample show violet or blue color. The result of observation of head squash microscopic preparations is shown in Figure 2.

The immunohistochemical examination of dengue virus in Aedes spp. in the Brontokusuman revealed that the highest 7\% TTI values were observed in RW (Rukun Warga) and while it was $5 \%$ in RW 13. In other three locations, RW 4, RW 9 and RW 18, there were no mosquitoes found positive for dengue virus, hence, the TTI value was $0 \%$ (Table 1). Overall, 3 samples of positive dengue virus were found from 100 samples and the TTI value was $3 \%$.

\section{Resistance status to cypermethrin (Monooxygenase Enzyme Activity)}

Biochemical assay was carried out to determine the mechanism of resistance in the Aedes spp. in the Brontokusuman Village. The chemical test based on enzyme activity monooxygenase was conducted to know the process of cypermethrin resistance. In the test were used $3^{\text {rd }}$ instar of Aedes spp. Larvae. The low to high resistance status found in every place (RW) of Brontokusuman Village. The Aedes spp. mosquitoes which are classified as highly resistant only found in RW 7 and RW 13 (Table 2).

Table 1. The value of the Transovarial Transmission Index (TTI) of dengue virus in Brontokusuman Village, Mergangsan Subdistrict, Yogyakarta City, Indonesia

\begin{tabular}{cccc}
\hline & \multicolumn{2}{c}{ Total } & TTI (\%) \\
\cline { 2 - 3 } Location & $\begin{array}{c}\text { Positive } \\
\text { sample }\end{array}$ & $\begin{array}{c}\text { Negative } \\
\text { sample }\end{array}$ \\
\hline RW 4 & 0 & 20 & $0 \%$ \\
RW 7 & 2 & 20 & $10 \%$ \\
RW 9 & 0 & 20 & $0 \%$ \\
RW 13 & 1 & 20 & $5 \%$ \\
RW 18 & 0 & 20 & $0 \%$ \\
\hline
\end{tabular}

Note: RW = Rukun Warga

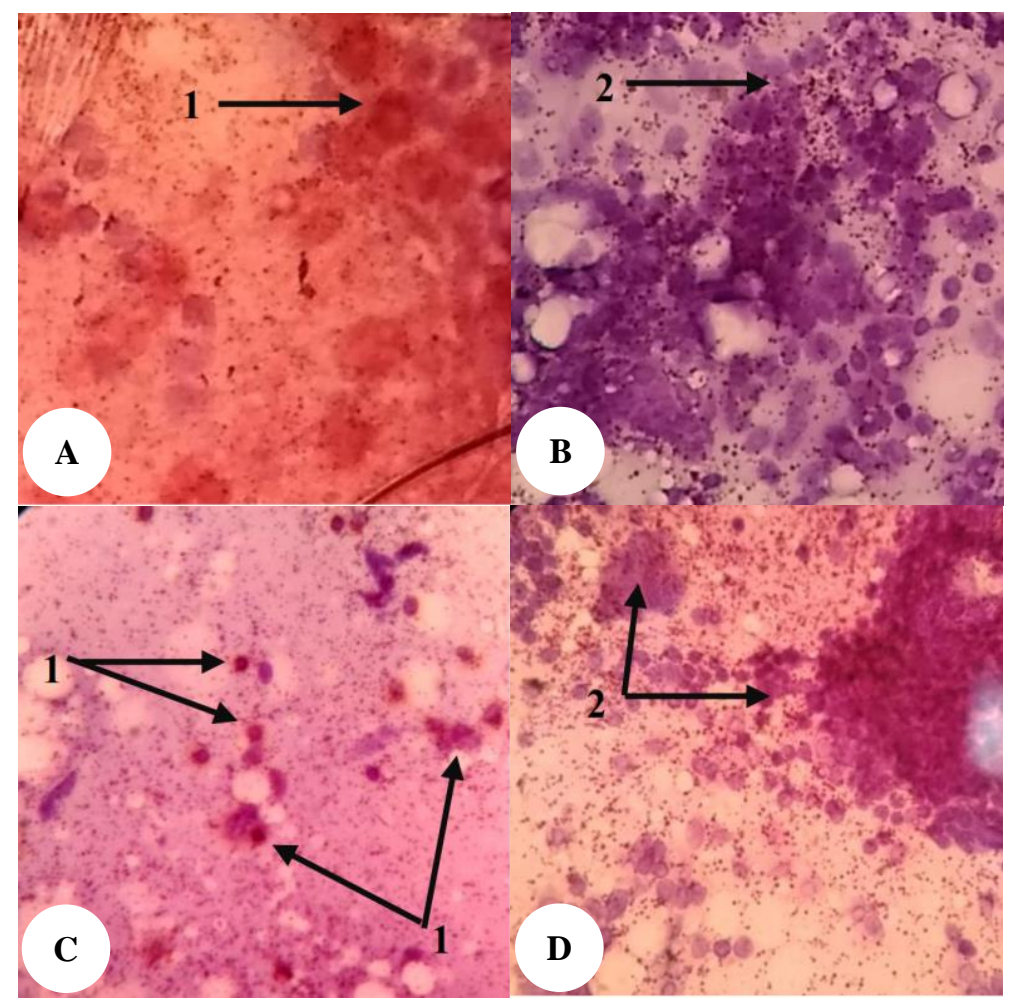

Figure 2. Female mosquito head squash preparations for dengue virus assay with ISBPC method. A. Positive control, B. Negative control, C. Positive sample, D. Negative sample. 1. Positive cell (brown), 2. Negative cell (violet/blue) (100x10 magnification) 
Table 2. Resistance status of Aedes spp. in Brontokusuman Village, Mergangsan Sub-district, Yogyakarta City, Indonesia against cypermethrin insecticide by biochemical assay and reading use Elisa Reader $(\alpha=655 \mathrm{~nm})$

\begin{tabular}{|c|c|c|c|c|c|c|c|c|c|c|}
\hline \multirow{3}{*}{ Resistance status } & \multicolumn{10}{|c|}{ Number of mosquitoes per location } \\
\hline & \multicolumn{2}{|c|}{ RW 4} & \multicolumn{2}{|c|}{ RW 7} & \multicolumn{2}{|c|}{ RW 9} & \multicolumn{2}{|c|}{ RW 13} & \multicolumn{2}{|c|}{ RW 18} \\
\hline & No. & $\%$ & No. & $\%$ & No. & $\%$ & No. & $\%$ & No. & $\%$ \\
\hline $\begin{array}{l}\text { Very Sensitive (susceptibility) } \\
\text { (AV value }<\text { Average of negative control }+3 \text { SD) }\end{array}$ & 4 & 80 & 2 & 40 & 3 & 60 & 0 & 0 & 3 & 60 \\
\hline $\begin{array}{l}\text { Moderate Resistant } \\
\text { (Average of negative control }+3 \mathrm{SD} \leq \mathrm{AV} \text { value } \leq \text { Average of } \\
\text { positive control) }\end{array}$ & 1 & 20 & 2 & 40 & 2 & 40 & 1 & 20 & 2 & 40 \\
\hline $\begin{array}{l}\text { High Resistant } \\
\text { (AV value > Average of positive control) }\end{array}$ & 0 & 0 & 1 & 20 & 0 & 0 & 4 & 80 & 0 & 0 \\
\hline Total & 5 & 100 & 5 & 100 & 5 & 100 & 5 & 100 & 5 & 100 \\
\hline
\end{tabular}

Note: RW = Rukun Warga

Table 3. The percentage of mortality and the resistance category of Aedes spp. in Brontokusuman Village, Mergangsan Subdistrict, Yogyakarta City, Indonesia

\begin{tabular}{lcccc}
\hline \multirow{2}{*}{ Treatment } & \multicolumn{3}{c}{ Parameter } \\
\cline { 2 - 5 } & $\begin{array}{c}\text { No. Dead } \\
\text { Mosquitoes }\end{array}$ & $\begin{array}{c}\text { No. Live } \\
\text { mosquitoes }\end{array}$ & $\begin{array}{c}\text { Mortality } \\
(\%)\end{array}$ \\
\hline R 1 & 8 & & 2 & $80 \%$ \\
R 2 & 5 & 5 & $50 \%$ \\
R 3 & 8 & & 5 & $80 \%$ \\
R 4 & 6 & & 4 & $60 \%$ \\
Control & 0 & & 10 & $0 \%$ \\
\hline
\end{tabular}

Note: $\mathrm{R}=$ Replication

\section{Cypermethrin resistance status of Aedes spp. mosquitoes}

The resistance status of cypermethrin was carried out by bioassay method using 10 female mosquitoes of the Aedes spp. in each treatment. Classification of resistance status refers to Kemenkes (2018) which states that the average mortality value $<80 \%$ includes resistance and mortality $80-97 \%$ presumed cypermethrin resistance. The test results showed that the resistance status of Aedes spp. in Brontokusuman can be presumed resistance to cypermethrin with a percentage of $80 \%, 50 \%, 80 \%$, and $60 \%$. The results of the cypermethrin test can be observed in Table 3.

\section{Discussion}

The mosquitoes samples used for this study were obtained from larvae collected from five place (RW) of Brontokusuman. In the study, only female mosquitoes were used because the female mosquitoes played an important role in transmitting the virus while sucking blood. The average age of mosquitoes was 7 days with the aim to provide time for virus to replicate. The dengue virus enters the body of the mosquito and generally replicates in the salivary gland for 8-10 days (Sukohar 2014).

The transovarial transmission test in the female mosquito's body was carried out by immunohistochemical assay using the Head Squash method. Dengue virus that replicates in the salivary gland, was also found in brain tissue (Mendoza et al. 2002). The presence of dengue virus in the cells of brain tissue or caput can be detected with the head squash method. Appearance of brown cells in the head squash preparation indicated the presence of dengue antigen. The antigen reacts with the primary antibody. The presence of primary antibodies could be recognized by secondary antibodies labeled with biotin. The antibody complex binds to the enzyme HRP labeled streptavidin conjugate (Horseradish Peroxidase). This enzyme degraded the DAB (Diaminobenzidine) substrate and cause the brown appearance of cells (Widiastuti et al. 2012). The cells in the preparation slide become blue colored dafter adding of HE (Hematoxylin-Eosin) dye if there is no dengue antigen.

In this research, the number of cells infected with the virus is less than normal cells (colored blue), indicated low number of viruses having the ability to infect cells. Dengue virus has not undergone complete replication to infect all of the cells. The presence of transovarial transmission can be determined by the TTI (Transovarial Transmission Index) by calculating the percentage of the number of positive samples of dengue virus (Purnama et al. 2017). The positive samples were only found in mosquitoes from two RW with TTI in RW 7 of $10 \%$ and 5\% in RW 13. There was no transovarial transmission of dengue virus in Aedes spp. from other three sampling locations. The TTI value obtained in this study was lower than the TTI value (16.16\%.) of the city of Yogyakarta which was examined by Umniyati (2009). The number of Aedes spp. mosquitoes that can transmit the dengue virus in Brontokusuman was low. The location and area of sampling can affect the existence of mosquito vectors. The DHF cases in Brontokusuman Village were observed lower than the DHF cases in the previous years. In other words, there were only few hosts (human) infected with the dengue virus.

The transovarial transmission of dengue virus was found only in two locations in Brontokusuman Village which indicate that there is a process of maintaining the virus. The viruses are transmitting in to eggs followed by further development into larvae, pupae, and mosquitoes that contain dengue viruses (Joshi et al. 2002). The TTI values can be influenced by several factors including the density of vectors and the condition of eggs. If the number of vectors increases, the possibility of infection also increases. In the field sampling, the number of larvae 
obtained was few, so the potential for the virus transmission was also low. Low number of samples (20 only) can also be one of the possible reasons. There was a possibility, if the mosquito tested does not contain the dengue virus. Conditions of the eggs can also affect the sustainability of eggs (Joshi et al. 2012). If the eggs are damaged, and cannot hatch, the number of larvae that hatch from infected eggs will decrease.

The resistance status of mosquito against cypermethrin insecticide was tested by biochemical and bioassay methods. Based on the biochemical assay (Table 2), the F1 generation mosquitoes from the Brontokusuman Village were generally categorized to sensitive or susceptible against cypermethrin. The results revealed that the enzyme monooxygenase activity was still low. However, there were five mosquitoes which grouped into high resistance reflected high activity of monooxygenase enzyme. The high resistance status was only found in RW 7 and RW 13, while, RW 4, RW 9 and RW 18 were categorized as sensitive to moderate resistant. The results of individual mosquitoes/larvae used were different, so the level of resistance and activity of the monooxygenase enzyme was also different. Basically, biochemical method is specific to test of enzyme activity. Nevertheless, vector resistance to insecticides not only caused by increasing of enzyme activity, but also the presence of knockdown resistance gene (kdr) as genetic factors (Pradani et al. 2018). The activity of enzymes monooxygenase will be highly related to the increased pyrethroid group resistance including cypermethrin (Pimsamarna et al. 2009). In the insect's body, the enzyme monooxygenase is able to detoxify the pyrethroid insecticide group (Scott 2008).

In the bioassay method, 10 mosquitoes per sample were used to fulfill the requirement of minimum number as suggested by Kemenkes (2018). However, this step was not applied to all RE samples due to the limited number of mosquito samples. From the bioassay results (Table 3), it was known that the Aedes spp. mosquitoes from Brontokusuman Village have been presumed resistant to stated resistant against cypermethrin insecticide. There were $\leq 80 \%$ mosquito deaths from the total sample, so it could be classified as resistant. There were 50 and $60 \%$ of mosquito deaths recorded for the other replication and classified as presumed cypermethrin resistant. However, these results still need to be clarified again, with a greater number of samples and with increased dose (5 times the original dose) to determine the policy of using pyrethroid insecticides (Kemenkes RI, 2018).

The Aedes spp. mosquito from Brontokusuman Village have shown resistance mechanism against cypermethrin insecticide, although the mechanism was not caused by increasing of the activity of monooxygenase enzyme. The vector resistance may affect the survival of mosquitoes infected with the virus. Because of those reasons, application of the cypermethrin as an insecticide needs to be reconsidered. The mosquitoes which infected with the dengue virus and categorized as resistant population had potential to remain in nature and transmission can occur higher. In the study, the high resistance mosquito population was found in the same location with the mosquito population which had transovarial transmission, so we must increase early awareness about mosquito-borne disease. The other ways such as rolling out or replacing cypermethrin with other kinds of insecticides or applying the other control methods, such as managing the environmental sanitation should be implemented.

Based on the research, it could be seen that the incidence of transovarial transmission of dengue virus in Aedes spp. mosquitoes from Brontokusuman Village was found in 3 of 100 samples, with a TTI value of $3 \%$ (low category). The existence of transovarial transmission was influenced by many factors such as the number of DHF cases, vector density, and condition mosquito eggs. The results of the resistance status of Aedes spp. against cypermethrin by bioassay showed that the Aedes spp. mosquitoes from Brontokusuman Village categorized as presumed resistant and can be stated resistant Increase in enzyme monooxygenase activity was observed in biochemical test. The bioassay results have shown that there are mosquitoes which resistant to cypermethrin, but it could not be related to the results from biochemical assay. Therefore, further research is needed.

\section{ACKNOWLEDGEMENTS}

Authors acknowledge the contribution of Faculty of Biology and Faculty of Medicine, Universitas Gadjah Mada, Yogyakarta, Indonesia for the supports and cooperation during this research.

\section{REFERENCES}

Andriyoko B, Parwati I, Tjandrawati A, Lismayanti L. 2012. Penentuan serotipe virus dengue dan gambaran manifestasi klinis serta hematologi rutin pada infeksi virus dengue. Majalah Kedokteran Bandung 44: 253-260. [Indonesian]

Angel B, Joshi V. 2008. Distribution and seasonality of vertically transmitted dengue viruses in Aedes mosquitoes in arid and semi-arid areas of Rajasthan, India. J Vector Borne Dis 45: 56-59.

Biswas S, Dicks MDJ, Long CA, Remarque EJ, Siani L, Colloca S, Cottingham MG, Holder AA, Gilbert SC, Hill AVS. 2011. Transgene optimization, immunogenicity and in vitro efficacy of viral vectored vaccines expressing two alleles of Plasmodium falciparum AMA1. PLoS ONE 6 (6): e20977. DOI: 10.1371/journal.pone.0020977.

Brogdon W, Chan A. 2010. Guidelines for Evaluating Insecticide Resistance in Vectors using the CDC Bottle Bioassay. CDC Technical Report, CDC Atlanta USA.

Depkes. 2005. Pencegahan dan Pemberantasan Demam Berdarah Dengue di Indonesia. Depkes RI, Jakarta. [Indonesian]

Halstead SB. 2008. Dengue virus-mosquito interactions. Annu. Rev. Entomol. 53: 273-291.

Joshi V, Mourya DT, Sharma RC. 2002. Persistence of Dengue-3 Virus Through Trans-ovari Transmission Passage in Successive Generations of Aedes aegypti Mosquitoes. Am J Trop Med Hyg 67: 158-61.

Kemenkes. 2015. Demam Berdarah Dengue (DBD). http: //www.depkes.go.id pada 15 Januari 2019. [Indonesian]

Kemenkes. 2018. Infodatin DBD 2017. Pusat Data dan Informasi Kementerian Kesehatan RI, Jakarta Selatan. [Indonesian]

Kemenkes. 2018. Panduan Monitoring Resistensi Vektor terhadap Insektisida. Kemenkes RI. Jakarta Selatan. [Indonesian]

Lee Y, Hu H, Kuo S, Lei H, Lin Y, Yeh T, Liu C, Liu H. 2013. Dengue virus infection induces autophagy: An in vivo study. J Biomed Sci 20: 65-76.

Mardihusodo SJ, Satoto TBT, Mulyaningsih B, Umniyati SR, Ernaningsih. 2007. Bukti Adanya Penularan Virus Dengue Secara 
Trans-ovari pada Nyamuk Aedes aegypti di Kota Yogyakarta. Simposium Nasional Aspek Biologi Molekuler, Patogenesis, Manajemen dan Pencegahan. Pusat Studi Bioteknologi UGM, Yogyakarta. [Indonesian]

Mendoza MY, Benito JSS, Mendoza HL, Martinez SH, Del Angel RM. 2002. A putative receptor for dengue virus in mosquito tissue: Dengue localization of a 45-KDA glycoprotein. Am J Trop Med Hyg 67 (1): 76-84.

Mulyatno KC, Yamanaka A, Yotopranoto S, Konishi E. 2012. Vertical transmission of dengue virus in Aedes aegypti collected in Surabaya, Indonesia, during 2008-2011. Jon J Infect Dis 65: 274-276.

Palgunadi BU, Rahayu A. 2011. Aedes aegypti sebagai vektor penyakit demam berdarah dengue. e Journal Universitas Wijaya Kusuma Surabaya 2 (1): 3-4. [Indonesian]

Pimsamarn S, Sornpeng W, Akksilp S, Paeporn P, Limpawhayakul M. 2009. Detection of insecticide resistance in Aedes aegypti to organophosphate and synthetic pyrethroid compounds in the NorthEast of Thailand. Dengue Bull 33: 194-202.

Pradani FY, Ipa M, Marina R, Yuliasih Y. 2011. Status Resistensi Aedes aegypti dengan Metode Susceptibility di Kota Cimahi terhadap Cypermethrin. Aspirator 3 (1): 18-24. [Indonesian]

Pramestuti N, Widiastuti D, Raharjo J. 2013. Transmisi Trans-Ovari Virus Dengue pada Nyamuk Aedes aegypti dan Aedes albopictus di Kabupaten Banjarnegara. Jurnal Ekologi Kesehatan 12 (3): 187-194. [Indonesian]

Purnama SG, Kardiwinata P, Satoto TBT. 2017. Detecting Transovarial Infection in Aedes aegypti Based on Immunocytochemica Streptavidin Biotin Peroxidase Complex Assay (ISBPC) in Bali. Seminar Nasional Sains dan Teknologi, Kuta. [Indonesian]

Ramadhani N, Nurhayati, Ismail D. 2017. Hubungan Karakteristik Tempat Perindukan dengan Keberadaan Vektor Demam Berdarah Dengue di Kelurahan Jati Kota Padang. Jurnal Kesehatan Andalas 6 (2): 331340. [Indonesian]

Reiskind MH, Zarrabi AA. 2012. Water surface area and depth determine oviposition choice in Aedes albopictus (Diptera: Culicidae) water surface area and depth determine oviposition choice in Aedes albopictus (Diptera : Culicidae). J Med Entomol 49 (1): 71-76.

Rohani A, Zamree I, Lee HL, Mustafakamal I, Norjaiza MJ, Kamilan D. 2007. Detection of transovarial dengue virus from field-caught Aedes aegypti and Ae. albopictus larvae using C6/36 Cell Culture and
Reverse Transcriptase-Polymerase Chain Reaction (RT-PCR) Techniques. Dengue Bull 31: 47-58.

Satoto TBT, Listyantanto A, Agustjahjani SD, Joser HR, Widartono BS. 2018. Vertical Transmission of Dengue Virus in the Yogyakarta Airport Area. Environmental Health and Preventive Medicine 23 (22): 1-7.

Scott JG. 2008. Insect cytochrome P450s: Thinking beyond detoxification. Insect Physiol Toxicol Mol Biol. 2008: 117-204

Sukohar A. 2014. Demam Berdarah Dengue (DBD). Medula 2 (2): 1-15.

Thavara U, Siriyasatien P, Tawatsin A, Asavadachanukorn P, Anantapreecha S, Wongwanich R, Mulla MS. 2006. Double Infection of Heteroserotypes of Dengue Viruses in Field Populations of Aedes aegypti and Aedes albopictus (Diptera: Culicidae) and Serological Features of Dengue Viruses Found in Patients in Southern Thailand. Southeast Asian J Trop Med Public Health 37 (3): 468-76.

Thongrungkiat S, Maneekan P, Wasinpiyamongkol L, Prummongkol S. 2010. Prospective field study of transovarial dengue-virus transmission by two different forms of Aedes aegypti in an urban area of Bangkok, Thailand. J Vector Ecol 36 (1): 147-153.

Umniyati SR. 2009. Teknik Imunositokimia Menggunakan Antibodi Monoklonal Anti Dengue DSSC7 untuk Kajian Patogenesis Infeksi Virus Dengue dan Surveilansi Vektor. [Disertasi]. Universitas Gadjah Mada, Yogyakarta. [Indonesian]

Umniyati SR, Sutaryoa, Wahyono D, Artama WT, Mardihusodo SJ, Soeyokoa, Mulyaningsih B, Utoro T. 2008. Application of Monoclonal Antibody DSSC7 for Detecting Dengue Infection in Aedes aegypti Based on Immunocytochemical Streptavidin Biotin Peroxidase Complex Assay (ISBPC). Dengue Bull 32: 83-99.

Widiastuti D, Umniyati SR, Wijayanti N. 2012. Pemeriksaan virus dengue-3 pada nyamuk Aedes aegypti yang diinfeksi secara intrathorakal dengan teknik imunositokimia menggunakan antibodi DSSE10. Balaba 8 (1): 21-25. [Indonesian]

World Health Organization (WHO). 2000. Technique to Detect Insecticide Resistance Mechanisms (Field and Laboratory Manual). WHO Communicable Disease, Atlanta.

World Health Organization (WHO). 2009. Dengue: Guidelines for Diagnosis, Treatment, Prevention and Control. World Health Organization Press, Geneva.

Yacoub S, Farrar J. 2014. Dengue. In: Farrar J, Junghanss T, Kang G, Lalloo D, White NJ. 2014. Manson's Tropical Diseases. Elsevier Saunders, China. 